\title{
POHANKA JAKO FUNKČNÍ POTRAVINA
}

\section{Zdeněk Hon, Jiř́i Patočka}

10: $1-246,2008$

ISSN 1212-4117

Jihočeská univerzita vČeských Budějovicích, Zdravotně sociální fakulta, katedra radiologie a toxikologie

Naše potrava může být pro naše tělo lékem, jak říkal zakladatel moderní medicíny Hippokrates, ale také jedem. S rostoucím zájmem spotřebitelů o zdravou výživu lze předpokládat, že vzroste zájem o speciální typ zdravé výživy, tzv. funkční potraviny. Termínem „funkční potraviny“ (functional food) jsou označovány speciálně vyvinuté potravinářské produkty $z$ prrirozeně se vyskytujících složek a s kladnými účinky na určité „cílové“ funkce lidského organizmu účinky, které presahují jejich základní úlohu složek výživy. U některých potravin jsou jejich zdravotní účinky dávno známé: otruby působí proti zácpě, nenasycené mastné kyseliny snižují hladinu cholesterolu $\mathrm{v}$ plazmě a riziko koronárního onemocnění, potraviny s vysokým obsahem draslíku a nízkým obsahem sodíku snižují krevní tlak (Patočka et al., 2008). Výrobci funkčních potravin ale hledají nové aktivní složky, pokud možno takové, které je možno patentově chránit. $\mathrm{V}$ posledních letech se dostává do popředí zájmu pohanka, která představuje slibnou plodinu pro výrobu funkčních potravin.

Pohanka je díky svému využití často řazena mezi obiloviny, ve skutečnosti se jedná o jednoroční dvouděložní rostlinu, s botanickým názvem pohanka obecná či setá (Fagopyrum esculentum Moench.), patřící do čeledi rdesnovitých (Polygonaceae) a rodu Fagopyrum (Janča a Zentrich, 1996). Původně pochází ze střední a severní Asie, patrně z oblasti mezi Bajkalským jezerem a Mandžuskem. Do Evropy se dostala až ve 13 . století z východu, pravděpodobně při expanzi Mongolů a Tatarů. Na našem území se hojněji pěstovala od 16. století, a to zejména v horských oblastech na chudých půdách Beskyd, v karpatské oblasti a na východním Slovensku (Mladá a Procházka, 1987). Z Evropy se pohanka dostala také do Ameriky, kde byla pro svou krátkou vegetační dobu a vysokou výživovou hodnotu důležitou plodinou při osidlování USA a Kanady. Dnes dochází k renesanci jejího pěstování v Evropě, především pro její nutriční a pěstitelské vlastnosti. Kromě pohanky seté se v omezené míre pěstuje také pohanka tatarská (Fagopyrum tataricum Gärtner), zvaná tatarka. Pro svou vyšší odolnost nahrazuje pohanku setou ve vyšších polohách (Li a Zhang, 2001).

Plodem pohanky je jednosemenná trojboká nažka (Fagopyri semen) připomínající bukvici. Plody obsahují komplex vitaminů a řadu prvků, především draslík, fosfor, hořčík, vápník a ve stopách železo, selen, měd', mangan a zinek. $\mathrm{Z}$ vitaminů jsou $\mathrm{v}$ plodech pohanky zastoupeny především vitaminy B1 (thiamin), B2 (riboflavin), niacin, vitamin E a C (Raghuvanshi et al., 2001).

Léčebně zajímavý je obsah cholinu, který regeneruje jaterní buňky (hepatocyty) po poškození chorobami a alkoholem a rovněž skutečnost, že pohankové nažky obsahují radu plnohodnotných bílkovin. Obsah bílkovin v semenech pohanky je 10-14\%, obsah škrobu je od 55-70\%, olejnatost semen je 1,5-3,7 \%, obsah celkové vlákniny v semenech je 3,4-5,2 \% (Tưmová et al., 2007).

Pohankové nažky jsou uloženy ve tmavém tvrdém oplodí (slupce). Slupka je velmi tvrdá a odstraňuje se bud'to mechanicky, kdy nedochází ke znehodnocení živin a výsledná barva krup je světlá, anebo termicky s tím, že v tomto př́padě je většina živin znehodnocena a kroupy mají barvu hnědou. Slupky pohanky se využívají $\mathrm{k}$ př́pravě pohankového čaje nebo jako výpln̆ do polštářů.

$\mathrm{V}$ poslední době se využívá ke konzumaci i pohanková nat' (Fagopyri herba), která byla po dlouhá staletí využívána pouze jako krmivo pro zvírata. Nat' se využívá $\mathrm{k}$ výrobě pohankového čaje, sušená do salátů a polévek či k odšt'avnění do zelených džusů. Toto poslední použití pohankové natě však v sobě skrývá určitá rizika, protože nat' obsahuje toxický fagopyrin, který při akumulaci pod pokožkou způsobuje tzv. 
fagopyrismus - hyperfotosenzitivitu. Projevuje se toxickou reakcí při vystavení kůže slunečnímu záření. Pokožka během pár minut zrůžoví až zčervená a svědí. Reakce je doprovázena silnou přecitlivělostí na chlad a tento stav může trvat až několik dní. Tyto symptomy byly $\mathrm{v}$ minulosti popsány u dobytka živícího se pohankovou natí, protože ta byla člověkem konzumována pouze minimálně. $\mathrm{V}$ době značné popularity výroby zelených št'áv z čehokoli zeleného ovšem člověk začal konzumovat pohankovou nat' ve výrazně větším množství, a tak se díky vysoké koncentraci fagopyrinu objevil fagopyrismus i u člověka (Li a Zhang, 2001; Hinneburg a Neubert, 2005). Semena pohanky obsahují i proteiny, které mohou způsobit hypersenzitivní reakci. Hlavní alergizující protein je Fag e 1. Bylo identifikováno osm epitopů a rozhodující aminokyseliny pro vazbu s IgE (Tsybina et al., 2004). Alergická reakce se projevu ekzémem, koprrivkou a výjimečně astmatickým záchvatem.

Dalšími pozitivními složkami pohanky jsou především flavonoidy rutin, isoorientin, orientin, vitelin a proteiny vázající thiamin. Obsah flavonoidů a jejich složení se liší podle druhu pohanky. Obecně platí, že obsah v F. tataricum (cca 40 $\mathrm{mg} / \mathrm{g})$ je vyšší než v F. esculentum (cca $10 \mathrm{mg} / \mathrm{g}$ ) (Li a Zhang, 2001). Nejdůležitější obsahovou látkou $\mathrm{v}$ kvetoucí nati a ve slupkách plodů je právě flavonoid rutin (vitamin $\mathrm{P}$ ), který je jedním z př́rodních zdrojů i pro farmaceutický průmysl. Rutin patří do skupiny rostlinných antioxidantů, které působí blahodárně na obranyschopnost organizmu, na posílení stěn a pružnost krevních vlásečnic (Santos et al., 1999; Kim et al., 2005; Lee et al., 2007). Z více nenasycených mastných kyselin je významný obsah kyseliny linolenové a linolové. Lipidy z pohanky obsahuji $0,2 \%$ fyziologicky aktivních rostlinných sterolů (sitosterol, compesterol), kterým se přisuzuje řada farmaceutických účinků na chronická onemocnění, např. pưsobí proti virům, protinádorově, inhibují absorpci cholesterolu. Ve srovnání s kaseinem a proteiny z jiných plodin, např. sóji, dokáží bílkovinné extrakty $z$ pohanky účinněji snižovat hladiny cholesterolu v krvi, zvláště hladinu LDL a VLDL (Kayashita et al., 1997). Bílkovinné extrakty z pohanky lze využít jako složku přidávanou do potravin, která napomáhá léčit hypertenzi, obezitu, ale i zácpu. Pohanka je přirozeně bezlepková a vhodná pro nemocné celiakií.
V nedávné době byla z pohanky izolována látka, která je odpovědná za inhibici angiotenzin -konvertujícího enzymu (ACE), který konvertuje inaktivní angiotenzin I na aktivní angiotenzin II (Lapčík, 2006). Angiotenzin II, který působí na mnoha úrovních v lidském organizmu, je zodpovědný za navození vazokonstrikce, zvýšení aktivity sympatiku a nakonec i za stimulaci sekrece katecholaminů. Všechny tyto tři popsané účinky se $\mathrm{v}$ konečném výsledku podílejí na vzestupu hodnot krevního tlaku. Z 2,1 kg pohankové mouky vědci izolovali $57 \mathrm{mg}$ této účinné látky s inhibiční koncentrací $\mathrm{IC}_{50} 0,08 \mu \mathrm{M}$ směrem k ACE a rovněž se jim podařilo určit i její chemickou strukturu (2" hydroxy-nikotianamin) (Aoyagi, 2006).

Pohanka se využívá při léčbě křečových žil, hemoroidů, bércových vředů, ale i při poruchách prokrvení končetin, charakteristických červenými nitkami, a také jako prevence proti praskání cév, např. proti náhlým prŕhodám mozkovým. Konzumace pohanky chrání před srdečními chorobami a má posilující účinek na imunitní systém.

Podle nejnovějších výzkumů se ukazuje, že flavonoidy přecházejí přes placentu $z$ matky na plod a jsou důležité pro normální vývoj mozku a nervového systému. Klinické pokusy prokázaly vliv pohanky na zlepšení stavu pacientů s diabetem, aterosklerózou a dalšími chronickými chorobami (Li a Zhang, 2001). Klinické studie rovněž ukazují, že dieta bohatá na vlákninu z pohanky snižuje riziko vzniku rakoviny střev (Cassidy et al., 1994; Lipkin et al., 1999; Liu et al. 2001). Podle staré čínské medicíny je pohanka účinná léčivá bylina proti řadě onemocnění.

Z výše uvedeného vyplývá, že pohanka je bohatá na nutriční faktory a její aminokyselinové složení je kvalitnější než u řady jiných plodin. Rovněž flavonoidy mohou mít silné léčebné účinky, a proto se pohanka zdá být slibnou plodinou pro výrobu funkčních potravin.

\section{LITERATURA}

AOYAGI, Y.: An angiotensin-I converting enzyme inhibitor from buckwheat (Fagopyrum esculentum Moench) flour. Phytochemistry 2006. Vol. 67, no 6, s. 618-621.

CASSIDY, A., BINGHAM, S. A., CUMMINGS, JH.: Starch intake and colorectal cancer risk: an international comparison. Br J Cancer. 1994. Vol. 69, no 5, s. 937-942. HINNEBURG, I., NEUBERT, R. H.: Influence of extraction parameters on the phytochemical characteristics of extracts from buckwheat (Fagopyrum esculentum) herb. J Agric Food Chem. 2005. Vol. 53, no 1, s. 3-7. 
JANČA, J., ZENTRICH, J. A.: Herbář léčivých rostlin. 4. díl, 1. vyd., Praha: Eminent, 1996. s. 28-30.

KAYASHITA, J. et al.: Consumption of buckwheat protein lowers plasma cholesterol and raises fecal neutral sterols in cholesterol-Fed rats because of its low digestibility. J Nutr. 1997. Vol. 127, no 7, s. 1395-1400.

$\mathrm{KIM}$, KH. et al.: Optimal recovery of high-purity rutin crystals from the whole plant of Fagopyrum esculentum Moench (buckwheat) by extraction, fractionation, and recrystallization. Bioresour Technol. 2005. Vol. 96, no 15, s. $1709-1712$.

LAPČíK, O.: Pohanka a krevní tlak. Vesmír. 2006. Vol. 85 , no $11,644 \mathrm{~s}$.

LEE, SY. et al.: Growth and rutin production in hairy root cultures of buckwheat (Fagopyrum esculentum M.). Prep Biochem Biotechnol. 2007. Vol. 37, no 3, s. 239-246.

LI, SQ., ZHANG, QH.: Advances in the development of functional foods from buckwheat. Crit Rev Food Sci Nutr. 2001. Vol. 41, no 6, s. 451-464.

LIPKIN, M. et al.: Dietary factors in human colorectal cancer. Аnпи Rev Nutr. 1999. Vol. 19, s. 545-586.

LIU, Z. et al.: A buckwheat protein product suppresses 1,2 -dimethylhydrazine-induced colon carcinogenesis in rats by reducing cell proliferation. J Nutr. 2001. Vol. 131, no
6, s. 1850-1853.

MLADÁ, J., PROCHÁZKA, F.: Atlas cizokrajných rostlin, 1. vyd., Praha: Státní zemědělské nakladatelství, 1987. $250 \mathrm{~s}$.

PATOČKA, J. et al.: Nutriční toxikologie, 1. vyd., České Budějovice: ZSF JU, 2008. s. 13-54.

RAGHUVANSHI, RS., SINGH, R., SINGH, R.: Nutritional composition of uncommon foods and their role in meeting micronutrient needs. Int J Food Sci Nutr. 2001. Vol. 52, no 4, s. 331-335

SANTOS, K. F. et al: Hypolipidaemic effects of naringenin, rutin, nicotinic acid and their associations. Pharmacol Res. 1999. Vol. 40, no 6, s. 493-496.

TSYBINA, T. et al.: New protease inhibitors from buckwheat seeds: properties, partial amino acid sequences and possible biological role. Biol Chem. 2004. Vol. 385, no 5, s. 429-434.

TƯMOVÁ, L., PÍCHOVÁ, M., DUŠEK, J.: Fagopyrum esculentum in vitro. Ceska Slov Farm. 2007. Vol. 56, no 3, s. $125-128$

TƯMOVÁ, L., PÍCHOVÁ, M., DUŠEK, J.: Pohanka obecná a její terapeutické využití. Prakt. lékáren. 2007. Vol. 2, no 4, $190 \mathrm{~s}$. 